\title{
Gambaran Resiliensi Pada Ibu yang Memiliki Anak Thalasemia
}

\author{
Oleh: \\ Melisa Falentina' \& Agoes Dariyo ${ }^{2}$ \\ 1. ${ }^{2}$ Fakultas Psikologi, Universitas Tarumanagara Jakarta)
}

\begin{abstract}
Abstrak
Penelitian ini bertujuan untuk memberikan gambaran resiliensi pada ibu yang memiliki anak thalasemia. Resiliensi adalah suatu kemampuan seseorang di dalam menghadapi, mengatasi dan mampu melewati masamasa sulit di dalam hidup, sehingga seseorang dapat menjadi individu yang lebih kuat dari sebelumnya (Grotberg, 1995). Resiliensi perlu dimiiki oleh seorang ibu yang memiliki anak Thalasemia agar dapat mengatasi kesedihan dan bangkit untuk menjalani perannya dengan baik sebagai seorang ibu. Pengambilan data penelitian dengan menggunakan teknik wawancara mendalam (indepth interview) dilakukan terhadap empat orang ibu (berusia 38 sampai 53 tahun) yang memiliki anak thalasemia. Hasil penelitian ini menunjukkan bahwa keempat subyek menghadapi berbagai kesulitan ketika memiliki anak Thalasemia. Secara umum, keempat subyek mampu membangun resiliensi (/ have, / am, dan I can) di dalam mengatasi kesedihan dan mampu menjalankan perannya sebagai ibu dengan baik.
\end{abstract}

Kata Kunci: Resiliensi, Ibu, Anak yang Thalasemia.

\begin{abstract}
When a child diagnosed with thalassemia, it can cause a pressure for parents and it can be a challenge especially for mother in running her role as a mother for their children. Patients with thalassemia need blood transfusions for the rest of his life, and it is require a expensive cost. This study aims to provide an overview of resilience in mothers of children with thalassemia.
\end{abstract}


"Resilience is the human capacity to face, to cope, and to overcome the difficult times in life, so that someone be strengthened by experiences of adversity" (Grotberg, 1995). Resilience needs to be owned by a mother who has a child with thalassemia to be able to cope with sadness and rose to undergo their role as a mother. Data retrieval study using in-depth interview conducted towards four mothers (38 to 53 years old) who has a child with thalassemia. The result shows that the four subjects faced difficulties when they have the thalassemia children. Generally, the four subjects were able to build the resilience (I have, I am, I can) to cope the sadness, and able to perform their role as a mother very well.

Keywords: Resiliency, Mother, Thalasemia Children.

\section{Pendahuluan}

Di jaman modern ini, kesehatan semakin hari semakin kompleks. Lingkungan, situasi dan kondisi saat ini sangat berpengaruh bagi mudahnya berbagai penyakit berbahaya datang. Penyakit dapat menyerang siapa saja, baik laki-laki, perempuan, tua, muda, bahkan anak-anak sekalipun. Merupakan hal yang wajar ketika para orangtua mendambakan memiliki anak-anak yang sehat baik secara fisik dan psikis, mampu melewati tahapan perkembangan yang baik dan normal, bermain, dan menikmati setiap alur kehidupan yang pada umumnya dijalani oleh anak-anak lainnya. Namun, tidak semua orangtua dikaruniakan anak yang sehat. Beberapa di antaranya menderita penyakitpenyakit yang serius, seperti penyakit leukemia, atau penyakit kelainan darah yaitu Thalasemia (Kusumawardani, 2010). Penyakit yang disebabkan oleh kelainan genetik yang cukup banyak ditemukan pada anak adalah Thalasemia (Tamam, Hadisaputro, Sutaryo, Setianingsih, Astuti, \& Soemantri, 2010).

Thalasemia adalah merupakan penyakit keturunan yang terjadi karena adanya gangguan dalam pembuatan hemoglobin dalam darah (Ikatan Dokter Anak Indonesia (IDAI), 2005a). Hal yang sama juga diungkapkan oleh Broyles 
(dalam Wijayaningsih, 2013), yang mengungkapkan bahwa Thalasemia adalah penyakit herediter yang diturunkan berdasarkan kelainan hemoglobin, di mana satu atau lebih rantai polipeptida hemoglobin kurang atau tidak terbentuk sehingga mengakibatkan terjadinya anemia hemolitik. Secara garis besar sindrom Thalasemia dibagi dalam dua golongan besar sesuai kelainan berkurangnya produksi rantai polipeptida, yaitu jenis alfa dan jenis beta (Fakultas Kedokteran Universitas Indonesia (FKUI), 2004). Adanya gangguan pembentukan rantai globin ini menyebabkan terjadinya rantai globin abnormal. Hemoglobin dengan rantai globin abnormal tidak mampu mendistribusikan oksigen ke jaringan sehingga menimbulkan berbagai gangguan fungsi tubuh. (Tamam et al., 2010).

Saat ini Thalasemia merupakan penyakit keturunan yang paling banyak ditemukan di dunia, termasuk di Indonesia (Tamam, 2009). Data saat ini mengindikasi bahwa sekitar 7 persen dari populasi dunia adalah pembawa gangguan hemoglobin, dan 300.000-500.000 anak dilahirkan setiap tahun dengan tingkat homozigot berat pada penyakit ini (Aessopos, Angelucci, Antoniou, Chatterjee, Farmakis, Perrine, Sanctis, \& Walker, 2008). Hingga Maret 2009 kasus Thalasemia di Indonesia mengalami peningkatan sebesar 8,3 persen (Indanah, Yetti, \& Sabri, 2011) dari 3653 kasus yang tercatat pada tahun 2006 (Adriani, Rusmil, \& Hilmanto, 2012).

Di Indonesia, diperkirakan jumlah pembawa sifat Thalasemia sekitar 5-6 persen dari jumlah populasi. Jumlah pembawa sifat ini berbeda-beda dari satu provinsi ke provinsi lain. Provinsi paling tinggi sebagai pembawa sifat Thalasemia adalah Palembang, dengan persentase 10 persen, menyusul kemudian Makasar sebanyak 7,8 persen, Ambon sebanyak 5,8 persen, Jawa sebanyak 3-4 persen, dan Sumatera Utara sebanyak 1-1,5 persen (Tamam, 2009).

Thalasemia, khususnya Thalasemia beta merupakan kelainan genetik yang paling sering dijumpai di dunia, termasuk di Indonesia. Frekuensi gen Thalasemia di Indonesia sekitar 3-10 persen. Diperkirakan lebih dari 2000 kasus baru ada setiap tahunnya di Indonesia (lkatan Dokter Anak 
Indonesia (IDAI), 2005b). Di Rumah Sakit Dr. Cipto Mangunkusumo didapati sampai dengan akhir tahun 2008 terdapat 1442 pasien Thalasemia mayor yang berobat jalan di Pusat Thalasemia Departemen Ilmu Kesehatan Anak FKUIRSCM (Ikatan Dokter Anak Indonesia (IDAI), 2010).

Penderita Thalasemia memerlukan transfusi darah seumur hidupnya (IDAl, 2005b). Tidak heran bahwa bagi sebagian besar orangtua, mempunyai anak yang menderita Thalasemia merupakan beban berat, baik moral maupun material. Selain harus terus mengawasi perkembangan anak, biaya yang dibutuhkan untuk transfusi darah juga tergolong mahal, dapat menghabiskan uang jutaan rupiah setiap bulannya (Tamam, 2009). Hal tersebut merupakan salah satu beban dan tanggung jawab sebagai orangtua dari anak yang menderita penyakit Thalasemia.

Berdasarkan kondisi tersebut, ada individu yang mampu bertahan dan pulih dari situasi yang tidak menguntungkan, namun ada sebagian individu yang gagal, karena tidak berhasil keluar dan bangkit dari situasi yang tidak menguntungkan tersebut. Kemampuan untuk melanjutkan hidup setelah ditimpa kemalangan atau setelah mengalami tekanan yang berat bukanlah sebuah keberuntungan, tetapi hal tersebut menggambarkan adanya kemampuan tertentu pada individu yang dikenal dengan istilah resiliensi (Tugade \& Fredrikson, 2004). Gilligan (dalam Maclean, 2004) mendefinisikan resiliensi adalah sebagai satu set kualitas yang membantu seseorang untuk bangkit dari banyak efek negatif dari kesulitan yang dihadapi.

Resiliensi merupakan sekelompok makna bahwa individu dapat melakukan sesuatu yang lebih baik dari yang diharapkan. Terkadang resiliensi digunakan untuk merujuk kepada keterampilan koping umum dan juga mekanisme yang dapat membantu dari tantangan umum dalam kehidupan sehari-hari (Hill, Stafford, Seaman, Nicola, \& Daniel, 2007). Menurut Gilligan (dalam Hill et al., 2007) kunci dari resiliensi biasanya adalah kapasitas untuk menghadapi kesulitan berat, sehingga terdapat dua kondisi penting, yaitu berupa ancaman yang signifikan atau keadaan sulit, dan yang kedua berupa adaptasi positif. Resiliensi pada orangtua dari anak yang 
menderita penyakit Thalasemia akan berusaha bangkit dari keterpurukannya dan beradaptasi dengan lingkungan sekitarnya.

Grotberg (dalam Maclean, 2004) menggambarkan secara bersamaan penemuan pada sebuah International Resilience Project, yang mensurvei hampir 600 orang anak dan keluarganya pada 30 negara. la menemukan bahwa terdapat faktor dari resiliensi yang relevan, untuk berbagai tingkat dan dalam semua budaya, yaitu: (a) untuk dukungan eksternal dan sumber-sumbernya digunakan istilah '/ have', (b) dalam diri pribadi digunakan istilah ' $/ \mathrm{am}$ ', dan (c) untuk kemampuan interpersonal digunakan istilah' $l$ can'. Faktorfaktor tersebut akan membantu individu untuk dapat meningkatkan resiliensinya serta untuk bangkit dari permasalahan yang dialaminya dan beradaptasi dengan lingkungannya.

Pada kenyataannya peristiwa yang tidak diinginkan ini menimbulkan reaksi yang berbeda-beda bagi setiap orang. Ada orang-orang yang tidak dapat menerima, tetapi ada juga orang-orang yang justru bangkit dan bahkan mendapatkan hal-hal yang luar biasa di tengah-tengah kekecewaan yang dialaminya. Berbagai gejolak emosi muncul dalam diri orangtua bahkan sampai mengganggu kondisi fisik dan psikisnya. Tingkat gangguan ini berkaitan dengan sejauh mana orangtua memiliki daya resiliensi terhadap cobaan atau permasalahan yang sedang dihadapinya (Muniroh, 2010). Terutama anak-anak yang menderita penyakit serius seperti Thalasemia sangat membutuhkan dukungan orangtua dan keluarga (Diela, 2014).

Tidak semua keluarga khususnya orangtua dapat menerima dan menyesuaikan diri dengan cepat ketika menghadapi permasalahan tersebut. Dampak yang dirasakan juga sangat beragam, baik secara sosial, ekonomi maupun psikologis (Asyanti, 2013). Berkaitan dengan dampak sosial, Lawrence (dalam Asyanti, 2013) menyebutkan beberapa hasil studi tentang kondisi keluarga dengan anak yang memiliki penyakit kronis, yang dapat membawa dampak negatif terhadap hubungan antar pasangan suami istri, yaitu antara lain kurangnya waktu untuk pasangan, masalah komunikasi, 
tingginya angka perceraian, meningkatnya konflik dalam hubungan, meningkatnya tuntutan peran yang berlebihan dan menurunnya kepuasan dalam hubungan.

Berkaitan dengan dampak ekonomi, Stein (dalam Australian Institute of Health and Welfare (AlHW), 2005) menyebutkan bahwa perawatan pada anak dengan penyakit kronis sering kali sangat mahal, dan biaya ini menjadi lebih mahal lagi karena penyakit ini tetap ada selama periode yang panjang. Knafl (dalam Asyanti, 2013) menyebutkan bahwa karakteristik umum pada keluarga dengan penyakit kronis adalah kesedihan orangtua, meskipun orangtua biasanya tidak menampakkan depresi secara nyata, dan suasana hati orangtua membaik seiring berlalunya waktu dan beberapa masalah teratasi. Namun demikian, depresi tersebut dapat menyerang sewaktu-waktu. Depresi cenderung menjadi akut ketika orangtua menyadari bahwa anak tidak mencapai perkembangan yang berarti atau ketika orangtua melihat anak lain berkembang menjadi lebih mandiri dibandingkan anaknya.

Dalam studi longitudinal yang dilakukan oleh Watson (dalam Asyanti, 2013) terhadap keluarga yang memiliki anak dengan penyakit kronis, ditemukan hasil bahwa ibu memiliki skor stres dan kecemasan yang lebih tinggi dibandingkan dengan ayah. Hal yang sama juga diungkapkan dalam American Pychological Association (dalam Papalia, WendkosOlds, \& Duskin-Feldman, 2009) bahwa wanita cenderung dilaporkan mengalami stres yang lebih ekstrem dibandingkan pria (35 persen berbanding 28 persen) dan lebih memprihatinkan mengenai stres. Nampaknya lbu memiliki kemungkinan lebih besar mengalami permasalahan psikologis bila dibandingkan dengan ayah (Asyanti, 2013).

Perempuan memang diketahui lebih rentan mengalami stres dibandingkan dengan laki-laki. Hal ini berhubungan dengan hormon stres yang disebut corticotropinreleasing factor (CRF). Hormon CRF lebih erat terikat pada protein stres sel-sel otak perempuan, sehingga membuatnya lebih sensitif terhadap dampak dari perubahan hormon tersebut. Sedangkan pada laki-laki, otak dapat mengurangi kadar 
protein, menghentikan hormon dari pengikatan dan mengurangi dampaknya terhadap otak (Bararah, 2011).

Menurut studi wawancara terhadap lebih dari 43 ribu orang dewasa di Amerika Serikat pada survei yang dilakukan oleh Institute Health Service, dilaporkan bahwa 22,9 persen wanita mengalami depresi selama hidup mereka, dibandingkan dengan 13,1 persen pria mengatakan merasakan hal serupa (Nurlaila, 2011). Berdasarkan studi tersebut dapat diketahui bahwa wanita berpotensi cenderung lebih tinggi dalam mengalami stres.

Resiliensi menjadi faktor penting dalam kehidupan. Ketika perubahan dan tekanan hidup berlangsung begitu intens dan cepat, maka seseorang perlu mengembangkan kemampuan dirinya sedemikian rupa untuk mampu melewati itu semua secara efektif. Untuk mampu menjaga kesinambungan hidup yang optimal, maka kebutuhan akan kemampuan untuk menjadi resilien menjadi semakin tinggi (Muniroh, 2010).

Menurut Murray (dalam Muniroh, 2010) individu yang tidak memiliki resiliensi cencerung membutuhkan waktu lebih lama untuk mampu menerima segala permasalahan atau cobaan yang datang, dan sebaliknya jika individu memiliki resiliensi maka akan ia akan lebih kuat dan segera bangkit dari keterpurukan serta berusaha mencari solusi yang terbaik untuk memulihkan keadaannya. Oleh karena itu, penulis tertarik untuk meneliti bagaimana gambaran resiliensi pada ibu yang memiliki anak Thalasemia.

\section{Metode Penelitian}

Penelitian ini menggunakan metode kualitatif. Kriteria subyek di dalam penelitian ini adalah ibu yang memiliki anak Thalasemia dan mempunyai kriteria usia antara 38-53 tahun. Subyek yang akan diteliti adalah sebanyak empat orang. Teknik yang digunakan dalam penelitian adalah convenience sampling karena kriteria subyek yang diinginkan sesuai dengan kriteria subyek yang ingin diteliti dan juga adanya faktor kemudahan bagi peneliti. Metode pengumpulan data dalam penelitian ini adalah wawancara dan observasi. 
Penelitian pada subyek kedua (K) dan ketiga (T), wawancara dilaksanakan di rumah subyek dengan alasan kenyamanan subyek dalam proses wawancara. Selanjutnya pada subyek pertama (J) dan keempat (D), wawancara dilakukan di Rumah Sakit Umum Tangerang, dengan menggunakan ruang istirahat perawat dan ruang tunggu pasien.

Proses pengolahan data dilakukan setelah proses wawancara selesai. Setelah data didapatkan dari hasil wawancara subyek-subyek penelitian, penulis melakukan transkripsi verbatim dari masing-masing subyek. Data transkripsi tersebut kemudian akan dicoding (memberikan kode), lalu hasil coding dianalisis dan diinterpretasikan sesuai dengan data yang didapatkan pada waktu wawancara dan observasi.

\section{Hasil dan Pembahasan}

Di dalam penelitian ini terdapat hasil yang menunjukkan bahwa terdapat empat jenis kesulitan yang dialami ketika seorang ibu memiliki anak thalasemia. Jenis kesulitan yang pertama adalah tekanan ekonomi, jarak tempuh di saat berobat, pengasuhan anak thalasemia, dan juga pola makan dan minum anak thalasemia. Masing-masing subyek memiliki kesulitan yang berbeda-beda. Hanya satu dari empat kesulitan yang dialami oleh keempat subyek secara bersamaan yaitu pada kesulitan dalam hal ekonomi.

\section{Tabel 1 Jenis Kesulitan Ibu yang memiliki Anak Thalasemia}

\begin{tabular}{clllll}
\hline \multirow{2}{*}{ No. } & \multicolumn{1}{c}{ Keterangan } & \multicolumn{5}{c}{ Subyek } \\
\cline { 3 - 6 } & & J & K & T & D \\
\hline 1. & Tekanan ekonomi & $\sqrt{ }$ & $\sqrt{ }$ & $\sqrt{ }$ & $\sqrt{ }$ \\
2. Jarak tempuh saat berobat & $X$ & $\sqrt{ }$ & $X$ & $\sqrt{ }$ \\
3. & Pengasuhan & $X$ & $\sqrt{ }$ & $\sqrt{ }$ & $\sqrt{ }$ \\
4. & $\begin{array}{l}\text { Pola makan dan minum anak } \\
\text { Thalasemia }\end{array}$ & $\mathrm{X}$ & $\sqrt{ }$ & $\sqrt{ }$ & $\mathrm{X}$ \\
\hline
\end{tabular}

Hasil penelitian juga menunjukkan bahwa hampir keempat subyek memenuhi kriteria faktor-faktor pembentuk resiliensi. Namun hanya pada subyek J, yaitu pada satu item 
dari faktor I have dan satu item dari faktor I am hal tersebut tidak terpenuhi.

Tabel 2 Faktor-faktor pembentuk Resiliensi

\begin{tabular}{|c|c|c|c|c|c|}
\hline \multirow{2}{*}{ No. } & \multirow{2}{*}{ Keterangan } & \multicolumn{4}{|c|}{ Subyek } \\
\hline & & $\mathrm{J}$ & K & $T$ & D \\
\hline \multicolumn{6}{|c|}{ I have } \\
\hline 1. & $\begin{array}{l}\text { Mempunyai hubungan saling } \\
\text { percaya }\end{array}$ & $\sqrt{ }$ & $\sqrt{ }$ & $\sqrt{ }$ & $\sqrt{ }$ \\
\hline 2. & Struktur dan aturan rumah & $\sqrt{ }$ & $\sqrt{ }$ & $\sqrt{ }$ & $\sqrt{ }$ \\
\hline 3. & Role models & $x$ & $\sqrt{ }$ & $\sqrt{ }$ & $\sqrt{ }$ \\
\hline 4. & $\begin{array}{l}\text { Memberi semangat agar } \\
\text { mandiri }\end{array}$ & $\sqrt{ }$ & $\sqrt{ }$ & $\sqrt{ }$ & $\sqrt{ }$ \\
\hline 5. & $\begin{array}{l}\text { Akses kesehatan, pendidikan, } \\
\text { kesejahteraan, dan } \\
\text { pelayanan keamanan }\end{array}$ & $\sqrt{ }$ & $\sqrt{ }$ & $\sqrt{ }$ & $\sqrt{ }$ \\
\hline \multicolumn{6}{|c|}{ I am } \\
\hline 1. & $\begin{array}{l}\text { Perasaan dicintai dan sikap } \\
\text { yang menarik }\end{array}$ & $\sqrt{ }$ & $\sqrt{ }$ & $\sqrt{ }$ & $\sqrt{ }$ \\
\hline 2. & $\begin{array}{l}\text { Mencintai, empati, dan } \\
\text { altruistik }\end{array}$ & $\sqrt{ }$ & $\sqrt{ }$ & $\sqrt{ }$ & $\sqrt{ }$ \\
\hline 3. & Bangga pada diri sendiri & $x$ & $\sqrt{ }$ & $\sqrt{ }$ & $\sqrt{ }$ \\
\hline 4. & $\begin{array}{l}\text { Mandiri dan bertanggung } \\
\text { jawab }\end{array}$ & $\sqrt{ }$ & $\sqrt{ }$ & $\sqrt{ }$ & $\sqrt{ }$ \\
\hline 5. & $\begin{array}{l}\text { Dipenuhi dengan harapan, } \\
\text { keyakinan, dan kepercayaan }\end{array}$ & $\sqrt{ }$ & $\sqrt{ }$ & $\sqrt{ }$ & $\sqrt{ }$ \\
\hline \multicolumn{6}{|c|}{ I Can } \\
\hline 1. & Keterampilan berkomunikasi & $\sqrt{ }$ & $\sqrt{ }$ & $\sqrt{ }$ & $\sqrt{ }$ \\
\hline 2. & $\begin{array}{l}\text { Kemampuan memecahkan } \\
\text { masalah }\end{array}$ & $\sqrt{ }$ & $\sqrt{ }$ & $\sqrt{ }$ & $\sqrt{ }$ \\
\hline 3. & $\begin{array}{l}\text { Mengatur perasaan dan } \\
\text { dorongan diri sendiri }\end{array}$ & $\sqrt{ }$ & $\sqrt{ }$ & $\sqrt{ }$ & $\sqrt{ }$ \\
\hline 4. & $\begin{array}{l}\text { Mengukur temperamen diri } \\
\text { sendiri dan orang lain }\end{array}$ & $\sqrt{ }$ & $\sqrt{ }$ & $\sqrt{ }$ & $\sqrt{ }$ \\
\hline 5. & $\begin{array}{l}\text { Mencari hubungan yang } \\
\text { dapat dipercaya }\end{array}$ & $\sqrt{ }$ & $\sqrt{ }$ & $\sqrt{ }$ & $\sqrt{ }$ \\
\hline
\end{tabular}

\section{Diskusi}

Resiliensi sebagai suatu kemampuan individu dalam menghadapi situasi sulit atau tekanan yang berat, dan kemudian individu dapat bangkit kembali sehingga dapat 
menjadi individu yang lebih kuat dan lebih baik dari masa sebelumnya (Grotberg, 1995). Para subyek dalam penelitian ini telah menghadapi berbagai kesulitan ketika mereka memiliki anak-anak yang mengalami Thalasemia. Mereka adalah ibu rumah tangga. Namun ada di antara mereka yang bekerja, sehingga mereka mempunyai peran ganda. Seorang ibu yang memiliki anak Thalasemia harus menghadapi tuntutan bahwa ia harus tetap menjalankan perannya sebagai ibu dengan baik, mengurus rumah tangga, serta mengasuh anak-anaknya yang menderita Thalasemia, dan bahkan ada di antara mereka yang juga memiliki anak-anak selain anak-anak yang menderita Thalasemia. Dalam situasi yang sulit seperti itu, para subyek dituntut untuk mengembangkan resiliensi, yaitu kemampuan beradaptasi menghadapi kesulitan.

Luthar dan Zelazo (dalam Borkowski, 2007) mengungkapkan bahwa resiliensi tidak hanya berfungsi dengan baik saat mengalami kesulitan, tetapi juga adanya peningkatan kapasitas adaptif yaitu berkembang menjadi individu yang kuat atau lebih baik dari masa sebelumnya. Oleh karena itu, jika seorang ibu yang memiliki anak Thalasemia mampu menghadapi masa-masa sulit yang ada serta menjadi individu yang lebih kuat dari sebelumnya dan tetap menjalankan perannya sebagai seorang ibu dengan baik, maka hal tersebut menandakan bahwa ia dapat mengaktualisasikan kemampuan seorang individu yang resilien.

Di dalam penelitian ini, ketiga subyek (K, T, dan D) memenuhi seluruh faktor resiliensi '/ have' (Grotberg, 1995), namun hanya pada pada subyek $J$ tidak ditemukan bagian role models ('I have'). Hal tersebut tidak ditemukan pada J karena di dalam menjalani kehidupan sosialnya, J tidak terlalu banyak berhubungan dengan masyarakat atau dapat dikatakan menutup diri lingkungan luar. Dengan demikian, J mengandalkan dirinya sendiri dalam menjalani kehidupannya, di dalam berpikir, kemudian mengumpulkan solusi dalam setiap permasalahan yang ada, lalu menentukan solusi yang akan di ambil dan dijalaninya, sehingga bagi J tidak terdapat orang yang menjadi panutan untuknya di dalam menjalani kehidupan. 
Selain itu, bangga pada diri sendiri ( $\mathrm{I}$ am) pada $\mathrm{J}$ juga tidak terlihat. Berbeda dengan ketiga subyek lainnya (K, T, dan D) yang memenuhi seluruh faktor 'I am' (Grotberg, 1995). Memiliki anak Thalasemia adalah suatu pergumulan yang berat bagi seorang ibu, di mana Thalasemia adalah suatu penyakit kelainan genetik yang cukup banyak ditemukan pada anak-anak (Tamam, Hadisaputro, Sutaryo, Setianingsih, Astuti, \& Soemantri, 2010). Padahal, merupakan hal yang wajar ketika seorang ibu menginginkan memiliki seorang anak yang sehat baik fisik maupun psikis. Namun, ketika seorang anak dinyatakan menderita Thalasemia, hal tersebut menjadi tempaan bagi seorang ibu. Belum lagi seorang ibu harus menghadapi kenyataan bahwa anak-anak penderita Thalasemia harus menjalani transfusi darah setiap bulannya selama masa hidupnya (IDAI, 2005b). Dengan demikian, persoalan tersebut menjadi berat bagi seorang ibu. Hal tersebut juga yang mungkin menjadi suatu penghalang bagi J sehingga ia tidak dapat melihat suatu kebanggaan pada dirinya.

\section{Simpulan}

Berdasarkan hasil penelitian yang telah dilakukan, dapat disimpulkan bahwa terdapat kesulitan-kesulitan yang dialami oleh ibu yang memiliki anak Thalasemia, yaitu pertama adalah kesulitan dalam hal ekonomi (J, K, T, dan D), kesulitan di dalam jarak tempuh saat berobat ke rumah sakit ( $K$ dan $D)$, Kesulitan dalam pengasuhan yang dialami (K, T, dan D), kesulitan di dalam pola makan dan minum anak Thalasemia (K, dan T).

Hampir semua subyek ( J, K, T dan D) telah memenuhi 3 faktor pembentuk resiliensi yaitu 'I have', 'I am' dan 'I can'. Khusus subyek J tidak memenuhi bagian role model (I have), dan bangga pada diri sendiri ( $\mathrm{am}$ ). Sedangkan subyek K, T dan $D$ telah memenuhi semua faktor pembentuk resiliensi tersebut.

\section{Saran-saran}

Berdasarkan penelitian yang telah dilakukan, maka saran yang dapat diberikan oleh penulis adalah berupa saran untuk 
penelitian selanjutnya, serta saran yang berkaitan dengan manfaat praktis yang dapat dilakukan dan ditujukan oleh para ibu yang memiliki anak thalasemia, suami dan istri yang memiliki anak thalasemia, saran bagi anak-anak penderita thalasemia, dan juga bagi orang-orang yang memiliki anak normal (tidak menderita thalasemia).

Saran bagi penelitian selanjutnya. Penelitian selanjutnya disarankan menggunakan pendekatan kuantitatif. Penelitian dapat membahas mengenai peran pola asuh orangtua dalam pengembangan resiliensi pada anak yang Thalasemia. Kriteria subyek agar lebih dikontrol untuk penelitian selanjutnya antara lain mengenai pekerjaan dan juga status perkawinan yang dapat memberikan pengaruh terhadap resiliensi subyek. Selain itu, penelitian selanjutnya dapat mempertimbangkan dinamika emosi para ibu yang memiliki anak Thalasemia.

Kemudian juga dapat dilakukan penelitian terhadap anak yang menderita Thalasemia, serta dapat juga meneliti gambaran dukacita (grief) orangtua yang anaknya meninggal karena menderita Thalasemia. Saran lainnya dapat dilakukan penelitian pada resiliensi ayah dalam menghadapi anak yang menderita Thalasemia dengan pendekatan kualitatif. Peneliti selanjutnya juga diharapkan agar menggunakan sumbersumber referensi yang lebih beragam agar dapat memperkaya hasil penelitian.

Saran bagi para ibu yang memiliki anak Thalasemia. Para ibu yang memiliki anak thalasemia disarankan untuk dapat bangkit dari setiap permasalahan yang ada, serta terus memiliki harapan-harapan yang positif bagi masa depan anakanaknya. Hal tersebut dapat dilakukan dengan cara terus berdoa kepada Tuhan YME agar mendapat kekuatan, kemudian memperluas pergaulan sosial yang positif agar dapat terus aktif dan memiliki pola pikir yang positif, dan tidak ragu untuk menceritakan permasalahan yang dialami kepada orang yang dapat dipercaya agar dapat membuat beban yang dirasakan menjadi lebih ringan.

Saran bagi para suami dan istri yang memiliki anak Thalasemia. Bagi para suami dan istri untuk tetap bersabar dan kuat di dalam mengarungi biduk rumah tangga. Melakukan komunikasi positif secara intensif di antara 
anggota keluarga, agar tetap terjalin keharmonisan di dalam keluarga. Menyelesaikan permasalahan yang ada dengan kepala dingin agar mendapat hasil yang baik.

Saran bagi anak-anak penderita Thalasemia. Berfokus kepada kelebihan-kelebihan yang mereka miliki, serta mengembangkan apa yang menjadi bakat dan kemampuannya. Sehingga mereka dapat menjadi anak-anak yang tetap aktif.

Saran bagi mereka yang memiliki anak normal (tidak menderita Thalasemia). Dukungan social sangat penting bagi anak-anak penderita thalasemia dan juga keluarganya, oleh karena itu lingkungan diharapkan dapat menerima dan memberi dukungan sosial pada anak-anak Thalasemia, sehingga mereka yang menderita Thalasemia merasa bahagia sebab mendapat penerimaan sosial. 


\section{Daftar Pustaka}

Aessopos, A., Angelucci, E., Antoniou, M., Caterjee, R., Farmakis, D., Perrine, S., et al. (2008). Guidelines for the clinical management of thalasemia. Nicosia, Cyprus: Thalassaemia International Federation.

Adriani, N., Rusmil, K., Hilmanto, D. ( 2012). Faktor risiko masalah psikososial

pasien thalasemia mayor. Jurnal Indonesian Medical Association, 62, (2), 56-59.

Asyanti, S. (2013). Dinamika permasalahan pada orangtua yang memiliki anak dengan penyakit kronis dalam mengantarkan anak menjadi pribadi yang lebih sehat dan berkarakter tangguh. Diambil pada tanggal 25 Maret 2014 dari http://publikasiilmiah.ums.ac.id:8080/xmlui/handle/12 $3456789 / 3977$

Australian Institute of Health and Welfare. (2005). Selected Chronic Diseases Among Australia's Children. Bulletin No. 29. AlHW cat. No. AUS 62. Canberra: AlHW.

Bararah, V. F., (2011). Ibu rumah tangga atau kantoran punya tingkat stres yang sama. Diambil pada tanggal 22 April 2014 http://health.detik.com/read/2011/07/15/130408/16819 33/763/ibu-rumah-tangga-atau-kantoran-punyatingkat-stres-yang-sama

Diela, T. (2014). Penting... desain hunian untuk keluarga pasien kronis!. Diambil pada tanggal 25 Maret 2014 dari http://properti.kompas.com/ $\mathrm{read} / 2014 / 01 / 24 / 1838000 /$ Penting.Desain.Hunian.untu k.Keluarga.Pasien.Kronis. 
Fakultas Kedokteran Universitas Indonesia. (2004). Buku ajar: Ilmu penyakit dalam. Jakarta: Balai Penerbit Fakultas Kedokteran Universitas Indonesia.

Hill, M., Stafford, A., Seaman, P., Nicola, R., \& Daniel, B. (2007). Parenting and resilience. York, U.K.: Joseph Rowntree Foundation.

Ikatan Dokter Anak Indonesia. (2005a). Buku ajar: Hematologi-onkologi anak. Jakarta: Badan Penerbit IDAI.

Ikatan Dokter Anak Indonesia. (2005b). Standar pelayanan medis kesehatan anak. Jakarta: Badan Penerbit IDAI.

Ikatan Dokter Anak Indonesia. (2010). Pedoman pelayanan medis. Jakarta: Badan Penerbit IDAI.

Indanah, Yetti, K., \& Sabri, L. (2011). Analisis faktor yang berhubungan dengan "selfcare behavior" pada anak usia sekolah dengan Thalasemia mayor di RSUPN Dr. Cipto Mangunkusumo Jaarta 2010. Jurnal Ilmu Keperawatan dan Kebidanan, 2, (2), 138-148.

Kusumawardhani, Endah. (2010). Waspada Penyakit Darah Mengintai Anda. Yogyakarta. Hanggar Kreator.

Maclean, K. (2004). Resilience: What it is and how children and young people can be helped to develop it. Diambil pada tanggal 24 Maret 2014 dari http://www.cyc-net.org/cyc-online/cycol-0304resilience.html

Muniroh, S. M. (2010). Dinamika resiliensi orangtua anak autis. Jurnal Penelitian, 7, (2), 1-11.

Nurlaila, A. (2011). Cara pria dan wanita hadapi stres. Diambil pada tanggal 22 April 2014 dari http://life.viva.co.id/news/read/242409-cara-pria-danwanita-sikapi-stres 
Papalia, D.E., Wendkos-Olds, S., \& Duskin-Feldman, R. (2009). Human development (11 th ed.). New York: McGraw-Hill.

Tamam, M. (2009). Bagaimana mencegah penyakit thalasemia pada keturunan kita. Diambil pada tanggal 23 Maret 2014 dari http://www. suaramerdeka.com/v2/index.php/read/cetak/2009/11/0 5/86780/Bagaimana-Mencegah-Penyakit-Thalasemiapada-Keturunan-Kita

Tamam, M., Hadisaputro, S., Sutaryo, Setianingsih, I., Astuti, R., \& Soemantri, A. (2010). Hubungan antara tipe mutasi gen globin dan manifestasi klinis penderita Thalasemia. Jurnal Kedokteran Brawijaya, 26, 48-52.

Tugade M.M \& B.L. Fredrickson. (2004). Resilient individual use positive emotions to bounce back from negative emotional experiences. Journal of Personality and Social Psychology, 86,(2), 320-333.

Wijayaningsih, S. K. (2013). Asuhan keperawatan anak. Jakarta: Trans Info Media.

Wolin, S. J., \& Wolin, S. (1993). The resilient self: How Survivors of Troubled

Families Rise Above Adversity. New York: Villiard.

Yayasan Thalassaemia Indonesia. (2009). Thalassaemia: Apakah itu? Mengapa terjadi? Bagaimana mencegahnya? Jakarta: Yayasan Thalassaemia Indonesia. 